\title{
The Permanence of Place: Places And Their NAmes IN Irish Literature.*
}

\author{
PIOTR STALMASZCZYK
}

\section{Introduction}

This paper discusses the relation between places and their names as reflected in Irish literature. According to Robbie Hannan (1991: 19) attachment to place is among the strongest human emotions, explicitly revealed in literature. Celtic literature is 'saturated' with images of landscape and preoccupied with places and their names, landscape is constantly present in ancient sagas and bardic poetry, modern drama, short stories, novels and essays. The sense of place is explicitly manifest in medieval heroic tales (such as The Táin), and twentieth century novels (e.g. James Joyce's Ulysses) and poetry, or contemporary drama (e.g. Brian Friel's Translations). ${ }^{1}$ Patrick Sheeran (1988: 194) has observed that the idea of the Irish sense of place is: (a) a product of the native tradition; (b) it is a verbal or nominal preoccupation and has little to do with any actual cultivation of things; (c) it relates to death rather than to life. The principal aim of this paper is to further add to the above characteristics.

The act of naming makes places distinctive, due to it they become analyzable and identifiable elements of the landscape. Kearns \& Berg (2002: 285) even claim that "rather than being entities in the landscape, names are a constitutive component of landscape itself". They make this contention with reference to place-names and the process of naming in New Zealand; this claim, however, may be equally well applied to the Irish, or any other, context. Place-names single out portions of the landscape and provide an explicit link between nature and culture. Liam Mac Mathúna (1989-90: 155) maintains that the crucial cultural role of place-names arises from their function as elements which bind society to its physical environment and help mankind to get to know its physical landscape. He distinguishes two dimensions in which place-names are involved: in the synchronic dimension place-names identify and refer places, in the diachronic one, place-names "link us to our forbears" (Mac Mathúna 1989-90: 157). The same author notes elswhere that the function of place-names shifts from the descriptive domain to the referential plane (Mac Mathúna 2000: 284):

[a] transition which ultimately sets them apart from the regular vocabulary of a language. With the passage of time their constituent elements, morphological shape and syntactic relationship tend to distinguish them from the contemporary discourse of society.

Attachment to place may ultimately lead to the mythologizing of place-names. The mythological and invocative nature of places and their names is also stressed by Benedict Kiely (1982: 104), who observes that:

Places so loved, names so often repeated as if they were charms and words of power and invocations of the very spirit of place, gathered about them their own sanctities and mythological significance.

\footnotetext{
I am very grateful to Professor Tatyana Mikhailova and Dr Maxim Fomin for their kind invitation to contribute to the second volume of Studia Celto-Slavica. This paper incorporates and develops some of the ideas presented earlier in Stalmaszczyk \& Elmore (2001), and in Chapter 5 of Stalmaszczyk (2005).

1 The idea of the Irish sense of place has been extensively discussed in numerous studies, cf. Kiely (1982), Mac Cana (1988), Mac Mathúna (1989-91; 2000), Ó Cuív (1989-90), O’Flanagan (1986), Sheeran (1988), Stalmaszczyk (1991-93; 2005), Stalmaszczyk \& Elmore (2001), and the importance of Irish personal names has been studied by, among others, Ó Cuív (1986), Mikhailóva (2006), Mac Mathúna (2006).
} 
This article focuses on different manifestations of the 'sense of place' prevalent in Irish literature. ${ }^{2}$ For the purpose of the forthcoming discussion, I refrain from introducing any theoretical or interpretative framework, nevertheless I intend to show the variety of functions place-names assume in literature (and culture). Place-names (toponyms) belong to a subclass of proper names, and they are understood here as words or phrases used to indicate, denote and identify a particular geographical place, cf. O'Flanagan (1986: 112). As far as the idea of place is concerned, Geoffrey Grigson (1980: 31) offers a most attractive elucidation, identifying it with our external condition:

Place is our external condition: place is garden, field, landscape, woods, fells, springs, rivers, estuaries, beaches, valleys, villages, towns, streets. Place is sunshine, rain, snow, ice. It is west, east, north and south. It is where the seasons change.

The above poetic explanation comes from the introduction to The Faber Book of Poems and Places, and both it and the following poems testify to the claim that "poets make the best topographers"3 (though not necessarily the most exact ones).

I hope to show here that the use of topographical names in Irish literature fulfils not only an aesthetic function, but it is also deeply rooted in the tradition, expresses the writer's local loyalty, and performs an invocative function. The following sections concentrate on the functions of place-names as revealed in the Metrical Dinnshenchas and the Táin, on the 'sense of place', on the move from 'sense of place' to 'sense of displacement', and on the more recent rendering of the problem in Brian Friel's Translations.

\section{Metrical Dinnshenchas}

Viewed from the approach advocated by, among others, Benedict Kiely, Irish literature is unique in possessing an extensive collection of verse dealing almost exclusively with the history and origin of hundreds of places. The collection of 225 poems is known as the Metrical Dinnshenchas or "History of Places" (Ir. dinnshenchas or dindshenchas "the lore of the high places', from dinn 'any noteworthy or prominent place', and senchas 'history, story'). The noteworthy places include, among others, dwelling-places, battlefields, and natural features, such as mountains, rivers and lakes (the 'external conditions' mentioned by Grigson, above). The collection is associated with the Middle Irish period, and is dated from 887 to 1079 . The two stanzas quoted below, from Sliab N-Echtga II, are concerned solely with lakes and their names: ${ }^{4}$

Loch Gréine, Grían ingen Find,

Loch nIbrach i n-Ibar-glind,

Loch forsndessid Trom Tórach,

forsngaairet Corr Crúad-glórach (...)

[ Loch Greine (Grian was Find's daughter),

Loch Ibrach in Ibar-glend,

the loch by which Trom Torach settled,

which they call Corr Cruad-glorach, (...) ]

Loch ind Eich, loch ind Aige,

loch na nDrúad, loch na Dáime,

\footnotetext{
2 In the forthcoming discussion of 'Irish literature' I take into consideration predominantly literature composed in Irish, but also Irish literature in English. For a discussion of geographical names in Scottish Gaelic poetry, see Stalmaszczyk (2005).

3 This, rather unorthodox, claim was made by W. G. Hoskins, the famous English geographer and landscape historian, in The Making of the English Landscape, cf. Hoskins (1985: 17).

4 Quoted from the standard edition, Gwynn, ed. ([1991]: 306-307). The spelling of all Irish examples quoted in this article follows that of the consulted editions.
} 
loch Láig, loch na Fer Fuinid,

loch Nechtain, loch nAthguinig.

The Metrical Dinnshenchas are devoted to meticulous descriptions of places, their histories and folk etymologies (quite often very naïve), and not seldom the presentations of places confine themselves to long lists and enumerations, as in the second stanza above. Not surprisingly, Robin Flower (1947: 1) called this collection an "Irish Dictionary of National Topography". It has to be noted though, as pointed out by Hannan (1991: 20), that most of the explanations are "mere conjecture, which did not seem to bother the compilers, for their chief concern seems to have been to offer some kind of fascinating, and often fantastic, explanation for each name". Also Patrick Sheeran (1988: 192), commenting upon this type of topographical poetry, stated that:

However much an ability to tolerate - even enjoy - lists of things in poetry may be regarded as a sign of true devotion to the art, the topomania of the seanachies surely stretched that tolerance to the limit.

Sheeran writes about the 'topomania' of the story-tellers, John Foster moves even further, and discusses 'topolatry' in the Old Irish epics, and 'topophilia' in the writings of the literary revival. ${ }^{5}$ This topomania was mercilessly satirized in Flann O'Brien's renowned novel At Swim-Two-Birds (London, 1939). And more recently, John Minihane (1993: 63) has observed that in the early Middle Ages:

[T] he scholars of Ireland seem to be crazed with etymology. They produce works in poetry and prose on the derivation of place-names; they produce works on the derivation of proper names. They produce etymological dictionaries.

Poetry became etymology, and etymology resulted in poetry. Middle Irish bardic tracts mentioned dinnshenchas as one of the subjects of study for trainee-poets in their eighth year. The genre was popular, as is evident from the fact that "the twelfth-century Book of Leinster contains well over a hundred dinnshenchas poems as well as some seventy-five prose items of dinnshenchas" (Ó Cuív 1989-91: 93-94). Important collections are to be found in other great Irish manuscripts: the Book of Lecan, the Yellow Book of Lecan, the Book of Ballymote and the Book of Ui Maine. ${ }^{6}$ As has already been noted, the noteworthy and prominent places mentioned in the dinnshenchas include nature places like mountains, lakes, rivers or islands, but also royal sites and famous battle sites. The following invocation, the beginning of the first five poems on Tara, the royal residence of the Ard Rí (the High Kings of Ireland), is most characteristic of the poems in the collection (from Ó Cuív 1989-91: 103-104):

Temair Breg, cid ní diatá, indisid, a ollamna!

[ Tell, o poets, from what is the name Temair of Brega! ]

Yet another aspect of the dinnshenchas has been noted by Patrick O'Flanagan (1986: 112113), who claims that the collection:

[I]n reality amounted to much more than the felicitous description and naming of places; it involved the delimitation of boundaries, occasionally the suggestion of ownership and, sometimes assessment of land-quality. In all it amounted to a mode of medieval land valuation, a forerunner to the great surveys of the seventeenth and nineteenth centuries.

5 Cf. John Foster Fictions of the Irish Revival (Syracuse, 1987), discussed in Cisło (2003: 150).

6 For a brief discussion, see O Daly (1965) and Ó Cuív (1989-91). 
Place-names determined boundaries and thus imposed authority or ownership upon the area. This would result in generation upon generation of any one clan dominating any given townland (the smallest administrative division on the countryside apart from individual house or farmstead). One without the other would seldom exist. These remarks point to the very practical side of assigning names. The act of naming places (and people and events) was also considered significant in storytelling, which is connected with the importance of the mnemonic techniques used by the traditional storytellers, the seanachies. As observed by Proinsias Mac Cana (1988: 332): "The onomastic element is a familiar - one might almost say ubiquitous - feature of traditional Celtic verse and narrative". Place-names not only refer to actual itineraries, they not only function as aids for orientation, but they also serve as 'topographical punctuation marks' guiding the storyteller (and listeners) throughout the narrative.

One of the favorite devices of Irish storytellers was to include incidents which would explain the origin of the mentioned place-names. For example, one of the 'Romantic Tales', Sgéala Muice Meic Dhá Thó (The Tidings of Mac Dá Thó's Pig), opens with the following lines: ${ }^{7}$

Baoi brughaidh amhra oireaghdha do Laighnibh feacht ann dar bho comhainm Mac Dá Thó. Buí cú aige no imgheadh Laighne uile i n-aonló. Ailbhe dono ainm na con sin a quo Magh nAilbhe.

[ There was once a famous and renowned landowner of Leinster whose name was Mac Dá Thó. He had a hound which would circuit the whole Leinster in one day. Now the name of that hound was Ailbhe from whom is named the Plain of Ailbhe. ]

The story also closes with reference to the hound, the name of the plain, and the itinerary, and thus, metaphorically, etymology takes the whole narrative within parenthesis.

Paraphrasing Máirín $O$ Daly it may be said that one of the main purposes of this topographical and onomastic genre was to ensure the survival of the places and their names. ${ }^{8}$ Additionally, the topographical elements provide an appropriate frame for interpretation, they confine the geographical and psychological area. This aspect can be clearly seen in short poems, but also in longer forms, such as the Old Irish epic Táin Bó Cúailnge, briefly discussed below.

\section{Táin Bó Cúailnge}

Táin Bó Cúailnge (The Cattle Raid of Cooley) is the oldest and most important tale of the Ulster Cycle. The 'topographical' episode in the introductory part of the Táin mentions the whole itinerary of the cattle raid, and introduces it in a highly conventional way: ${ }^{9}$

In lúan iar samain is and documlaisef.

[ On the Monday after the autumn festival of Samain they set out. ]

In the subsequent itinerary more than 60 places are named, and the episode closes with an equally conventional phrase: ${ }^{10}$

\footnotetext{
7 This version of the text has been edited and translated by Caoimhín Breatnach (1996: 64-65). Cf. his comments on the role of place-names inserted at various places in different redactions of the story, Breatnach (1996: 23-27). An earlier version of the story was edited by Nora Chadwick, who remarks that "the list of names [in the final section] forms a tiny Dindshenchas for Co. Kildare and perhaps beyond" (Chadwick 1927: 52).

8 Cf. O Daly (1965: 63): "For to enshrine the legends in verse was to ensure their survival". Mac Mathúna (2000: 285) observes that "the tradition of dindshenchas suffered virtually terminal dislocation in the aftermath of the English conquest of Ireland, 1550-1700".

9 This line (and the next one) is from Táin Bó Cúailnge. Recension I, edited and translated by Cecily O'Rahilly (1976). The topographical episode is confined within lines 114-134 of the text.

10 According to O'Rahilly (1976: 244) this sentence is probably a scribal comment.
} 
Ár ropo thairsin sin dochótar céin co ráncatar Findabair.

[ For they had gone past all these places before reaching Findabair. ]

According to Ó Cuív (1989-91: 99), the oldest version of Táin Bó Cuailnge mentions over 350 place-names and in some cases earlier names are replaced by new ones, many of which are said to derive from incidents which took place during the course of the cattle-raid.

Thomas Kinsella, the translator of the epic, notes that one of the major elements of the Táin is its topography: "Place-names and their frequently fanciful meanings and origins occupy a remarkable place by modern standards" (Kinsella 1970: XIII). In his rendering, Kinsella provides both the original Irish forms and translations of the descriptive phrases in the itinerary, e.g.: ${ }^{11}$

This is the way they went (...):

by Tuaim Móna, the peat ridge,

through Cúil Silinne, where Carrcin Lake is now -

it was named after Silenn, daughter of Madchar,

by Fid and Bolga, woods and hills (...),

through Ord, 'the hammer' (...)

through the river Indiuind, 'the anvil' (...).

In an often quoted and analyzed fragment recounting the boyhood deads of Cú Chulainn, the future hero travels for the first time to Emain and asks his charioteer the names of a mountain, a cairn, and a plain. Ibor, the charioteer, tells him their names and stories: ${ }^{12}$

Adfét dó dano ainm cech prímdúne eter Themair ocus Cenandas. Adfét dó chétamus a n-íathu ocus a n-áthu, a n-airdirci ocus a treba, a ndúne ocus a n-arddindgnu.

[ So he told him the name of every chief fort between Temar and Cennannas. He named, moreover, their meadowlands and their fords, their renowned places and their dwellings, their forts and their fortified heights. ]

Knowledge of the dinnshenchas and tribal lore was of utmost importance not only for the bards and poets, but also for the warriors and the "candidates for initiation to heroic status" (Mac Cana 1988: 332). Additionally, it had highly practical value as it provided the young warrior with good knowledge of the area in which he would frequently find himself, cf. Hannan (1991: 19).

A very different type of itinerary may be found in the speech poems of Buile Suibne (The Madness of Sweeney), a late $12^{\text {th }}$ century prose narrative. Suibne Geilt ('Suibne the Madman', or 'Mad Sweeney'), the supposed author of these poems, was said to have lost his reason in the battle of Mag Rath (AD 639), and thereafter lived in the wilderness. In the poem known as Suibne in the Snow, Suibne describes his winter ordeal, and names of places play a vital role in this description: ${ }^{13}$

Utmall m'imirce in gach fath;

dom-ríacht beith gan chéill gan chonn;

do Muig Line for Muig Lí,

do Muig Lí for Life lonn.

11 From The Tain (1970: 63). In his notes on the text, Kinsella explains that "the descriptive phrases in this itinerary are translations of the names themselves (...) or else attempts to bring out points of significance" (1970: 262). Temar and Cennanns (or Cenandas) are identified with Tara and Kells, respectively.

12 Lines 700-702 from Táin Bó Cúailnge. Recension I. For extensive comments on the significance of this fragment, see Mac Cana (1988) and Hannan (1991).

13 Stanzas five, six and seven, from Murphy ([1998]: 139). 
[ Restless my wandering from region to region; it has befallen me to be without reason or wits; from Moylinny I wander over Mag Lí, from Mag Lí over the rough Liffey valley. ]

Saigim der Segais Sléibe Fúait;

ricim im rúaic co Ráith Móir;

dar Mag nAí, dar Mag Luirg luinn,

ricim co cuirr Crúacháin chóir.

[ I traverse Segas on the Fews mountains; in my rush I reach Rathmore; passing through Mag nAí and the Plains of Boyle, I reach the hill of goodly Crúachán. ]

Ó Shléib Chúa (ní turas tais)

ricim go Glais Gáille grinn;

ó Glais Gáille (grid céim cían)

ricim sair go Slíab mBreg mbinn.

[ From the Knockmealdown mountains (it is no easy expedition) I come to the river in pleasant Gáille. From the Gáille river (though it is a long journey) I make my way east to music-haunted Slieve Brey. ]

Whereas in the Táin the names reflect an authentic (at least to some degree) itinerary, in the above lines they rather sketch outlines of a projected imaginary map (or even a mind-map). In both cases, however, the use of names is tightly connected with the 'sense of place'.

\section{3. 'Sense of place'}

Even for somebody unacquainted with Celtic literature, it must seem obvious that "Place and Past haunt the Irish Poetic mind" (Hirst 1988: 208). ${ }^{14}$ And this is equally true of ancient Irish poetry and the famous sagas, bardic poetry composed in the classical period, modern Scottish Gaelic poetry, as well as twentieth-century Irish literature written in English (cf. the concern with places and place-names in W. B. Yeats, James Joyce, Patrick Kavanagh, Seamus Heaney, and Brian Friel, to mention the most prominent names only), and modern literary criticism, as best evidenced by the essays surveyed and amply quoted in this paper. The question asked by Daniel Corkery in the opening line of his short story The Ploughing of Leaca-na-Naomh, "With which shall I begin - man or place?", seems to be more than just a narrative convention, it directly points to the author's preoccupation with place (and, as becomes obvious in the course of the story, its name as well). ${ }^{15}$

As has been pointed out throughout this article, Irish literature abounds in texts which make extensive use of topographical names, as illustrated by the following fragments from several different Irish poems: ${ }^{16}$

Ionmhuin Dún Fiodhaigh is Dún Fionn

Ionmhuin is Dún os a gcionn

Ionmhuin Inis Droighneach de

Is ionmhuin Dún Suibne.

[ Lovable are Dun Fidga and Dun Finn

Lovable the fortresses above them

14 Cf. also Hannan (1991: 19): "Attachment to place is expressed in a wide range of literature in Irish, from the Old Irish period down to the present day".

15 Corkery's story is reprinted in the Penguin Book of Irish Short Stories, edited by Benedict Kiely (London 1981).

16 From Deirdre and the Sons of Usna, from Neeson (1985: 136). This poem is contemporary to the Ulster Cycle. 
Lovable the island of Driagende

And lovable the fort of Sweeney. ]

The next two fragments come from poems composed in the seventeenth century: ${ }^{17}$

Coire dhá Ruadh, a rí Túama,

atá eadroinn, eagail linn,

Coire Bhreacán blagh dar gconair,

do ghabh creatán omhain inn.

[ Between us, O King of Tuaim, is Coire dhá Ruadh,

I fear it: Coire Bhreacáin is part of our path,

trembling terror has laid hold of me. ]

Bóinn is Siúir is Sein-Leamhain

agus Suca nach sriobhmall,

adeirit na deighleabhair

gurab uasile tú a Shionann.

[ The Boyne and the Suir and the ancient Laune, and swift-streamed Suca, good books declare that thou art nobler than they, O Shannon. ]

Place-names, especially names of the most prominent places, can be also juxtaposed with personal-names, as in this short poem attributed to the wife of Áed Mac Ainmirech, king of Tara (slain in 598 AD): ${ }^{18}$

Batar inmuini trí toíb frisná fresciu aitherrech, tóebán Temro, toíb Taillten, toíb Áedo maicc Ainmirech.

[ Beloved were three sides

I cannot hope to see again, side of Tara, side of Tailltiu, side of Áed Mac Ainmirech. ]

A feature common to various genres of Irish and Scottish bardic poetry "is to mention places of historical importance for effect" (Hannan 1991: 24). Osborn Bergin, the editor and translator of Irish Bardic Poetry, from which the above fragments are quoted, points to one more important topic present in this poetry. Commenting on Fearghal Óg's Love of Ireland, he observes that its subject is "the love and longing of the exile, so common in modern Irish verse" (Bergin 1970: 37). The following three stanzas from Love of Ireland are illustrative: ${ }^{19}$

Beannacht go baile Phádruig,

Ard Macha an mhúir mhíonfhádbhuig,

'sgo ríoghDhoire na sreabh seang,

treabh as líonmhaire léigheann. (...)

17 The first fragment is from An Address to Aonghas of Islay, from Bergin (1970: 171); the English translation comes from the same source, p. 292. The second fragment comes from The Shannon, from Bergin (1970: 61); English translation p. 238.

18 From Carney (1967: 24-25), the poem was probably composed in the eighth century

19 From Bergin (1970: 38); English translation p. 226. 
Beannacht go hEas rámhach Ruaidh, go sruth Sligigh 's go seanMhuaidh: buaidh tar gach n-innbhear aige,

's go cuan mbinngheal mBuannaide.

Beannacht go Loch Éirne uaim,

's go Loch Gile an fhóid ioofhuair,

's go Loch ngeal bhfíonmhar bhFeabhail

na sreabh bhfíorghlan bhfoithreamhail.

[ A blessing to Patrick's city, Armagh of the wall smooth and soft-sodded, and to royal Derry of the slender streams, a home where learning is most plentiful.

A blessing to Assaroe of the oars, to the River of Sligo and the ancient Moy, and to the tuneful bright haven of the River Bonnet, which surpasses every estuary.

A blessing from me to Loch Erne, and to Loch Gill of the cool sward, and to bright Loch Foyle of the wine, with clear and wooded streams. ]

Love of Ireland is one of the numerous Irish poems composed around the relation between places and exile, the topic tackled with in more detail in the next section.

\section{From 'sense of place' to 'sense of displacement'}

In early Irish literature the motif of exile is especially frequent in the poems attributed to St. Columba (Colum Cille), the founder of the monastery on the island of Iona in the sixth century. One of the most famous poems attributed to the saint is known as Colum Cille's farewell to Ireland: ${ }^{20}$

Fuil suil nglais

Dechus Erind tar a hais

Nocan faicfi si se a le

Firu Erind nas a mná (...)

Bind a cleirig, bind a heoin

Min a hoicc gact a senoir

Uais a fir rebladh namairc

Uais a mná ré a ndighthabairt

[ There is a grey eye

That looks back on Erin;

It shall not see during life

The men of Erin nor their wives. (...)

Melodious her clerics, melodious her birds,

Gentle her youths, wise her seniors,

Illustrious her great men and nobles,

Illustrious her women for fond marriage. ]

In the above poems, the sense of place evolves into the sense of displacement. This change of accent is also visible in another twelfth-century composition associated with Colum Cille, Colum Cille in exile: ${ }^{21}$

\footnotetext{
20 Stanzas two and four, from Neeson (1985: 146-147), these are the 'literal translations'. For different renderings of stanza one, see Murphy ([1998]: 64-65) and Carney (1967: 86-87).

21 Stanzas one and nine of the poem, from Greene \& O'Connor, eds. ([1990]: 181-183). See also An Exile's Dream in Murphy ([1998]: 66-69) and the notes therein.
} 


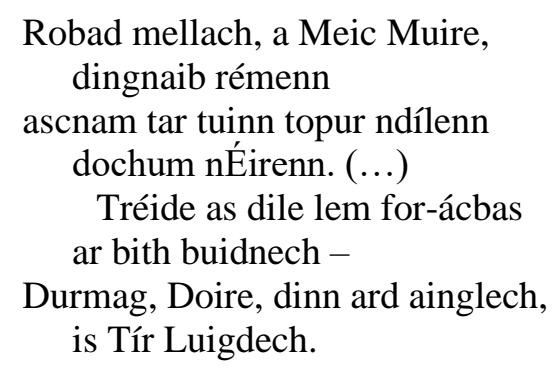

[ It would be delightful, Son of Mary, in strange journeys to travel over the sea, the well of floods, to Ireland.

I have left the three things I love best in the populated world -

Durrow, Derry, the high angelic homestead, and Tír Luigdech. ]

St. Columba's exile receives a most interesting modern rendering in Brian Friel's early play The Enemy Within. According to the author The Enemy Within is "neither a history nor a biography but an imaginative account, told in dramatic form, of a short period in St. Columba's thirty-four years of voluntary exile" (Friel 1979: 7).

For Friel's Columba the physical exile is conscious and self-imposed. Spiritually, however, matters are more complicated. In an exchange with Caornan, the copyist, the abbot of Iona agrees that he is well-known as a builder of churches and schools, but he immediately adds that "the inner man - the soul - [is] chained irrevocably to the earth, to the green wooded earth of Ireland!" (Friel 1979: 21). Still later, Columba bitterly remarks that "Home is a millstone round my neck" (Friel 1979: 32). And at the end of the play, the conflict between the 'inner man' and 'home' (Ireland) reaches its climax. Columba angrily reacts to his brother's and nephew's request to engage in some internal Irish tribal affairs and bursts out (Friel 1979: 75):

Get out of my monastery! Get out of my island! Get out of my life! Go back to those damned mountains and seductive hills that have robbed me of my Christ! You soaked my sweat! You sucked my blood! You stole my manhood, my best years! What more do you demand of me, damned Ireland? My soul? My immortal soul? Damned, damned, damned Ireland! - (His voice breaks) Soft, green Ireland - beautiful, green Ireland - my lovely green Ireland. O my Ireland -

Elaborating upon the topic of dinnshenchas, Sheeran (1988: 201) observed that: "Both ancient and modern examples of topomania in our literature clearly demonstrate that place names held magical potency and were invoked at times of crisis". Columba's invocation to Ireland in Friel's play undisputedly testifies to this claim. And, in intertextual terms, this final emotional rejection of Ireland may be regarded as a twentieth-century dramatic coda to the medieval poems and hymns quoted earlier.

Commenting recently on Seamus Heaney's poetry, the Polish poet and translator Jerzy Jarniewicz observed that for "Heaney, history reveals its often problematic meaning in language, particularly in place-names, and in landscape" (Jarniewicz 2002: 129), whereas Ronald Schuchard (1989: 4) writing about Heaney's essays, noted that "places become havens or heavens; they drive the poet into spiritual or physical exile", one may add that not only the poet, but also the reader. ${ }^{22}$ Another dimension of displacement has been added in more recent times: exile within Ireland, from villages into cities. In this case names of rural places are

\footnotetext{
22 Cf. also the following comments made by Kathleen Raine (1976: 6): "It is with intent that Yeats names in his poetry places and people who belong to Ireland's living inheritance; names deeply rooted in the national being of a people".
} 
contrasted with names of cities and towns. ${ }^{23}$ Myles Dillon (1965: 26) presents this issue in a broad historical perspective:

This motif of exile is echoed and re-echoed in Irish literature by the early missionaries, in bardic poetry, later by Franciscan friars in exile; and it runs through Irish history, the history of early and modern times, exile for Christ's sake in the early centuries; refuge from the Norse invasion later, the Flight of the Earls in 1607, the exile of the Wild Geese after Limerick, the exile of hundreds of thousands after the famine.

Obviously, this strong attachment to place is not confined to the Irish people and to the Irish literature, however, as remarked by Seán Ó Tuama (1985: 22):

One will probably find a reverential feeling for home-place in every country throughout the world, but it is unlikely that it is to be found so deeply rooted in any West European culture, at any rate, as it is in Irish culture. It seems to have made its presence felt in Irish literature at every level and in every era from early historic times to the present day.

Also Kiely (1982: 96) tries to explain the phenomenon and points to the 'island factor':

This attachment to place, to the home places, even the mythologizing of place-names, is not confined, obviously, to ourselves the Irish, nor even to island people. But it is possible that it may be more emphasized in the case of island people, and made more poignant when their destiny takes them far from the island of their earliest associations and affections, Ithaca or Ireland.

This remarkable feature of literature has to be seen against a very close relation between people and places in Ireland. According to the geographer and ethnographer E. Estyn Evans (1973: 66) there was always a strong sense of geographical personality in the older Irish literature connected with a sense of the harmony and mystery of man's place in nature. This strong connection between nature and place is very clearly seen in the 'lays and lyrics of the Fianna', anonymous $17^{\text {th }}$ century poetry with close affinity to the Old and Middle Irish nature literature: ${ }^{24}$

Sgolghaire luin Doire an Chairn, búithre an daimh ó Aill na gCaor, ceol le gcodladh Fionn go moch, lachain ó Loch na dTrí gCaol.

Cearca fraoich um Chruachain Chuinn, feadghail dobhráin Druim Dhá Loch, gotha fiulair Ghlinn' na bhFuath, longhaire cuach Chnuic na Scoth.

[ Throat-song of the blackbird of Doire an Chairn and the stag's call from Aill na gCaor were Fionn's music, sleeping at morn, and the ducks from Loch na dTrí gCaol,

the grouse at Cruachan, seat of Conn,

23 Cf. the discussion in Ó Tuama (1985). See also Hannan (1992: 26) on the attachment to place which finds expression in the pastoral, and the conflict between city life and rural life.

24 Stanzas six and seven of Beautiful Blackbird of Doire an Chairn, from Ó Tuama \& Kinsella (1990: 42-43). A similar 'litany' of different animal names may be found in the late $12^{\text {th }}$ century poem Suibne in the Woods, cf. Murphy ([1998]). 
otters whistling at Druim Dá Loch,

eagle cry in Gleann na bhFuath,

cuckoos' murmur on Cnoc na Scoth (...). ]

The use of topographical names fulfils not only an aesthetic function, but it is also deeply rooted in the tradition, expresses the writer's local loyalty, and performs an invocative function. Place-names are sometimes invoked in a rather general way, on other occasions they are cited for narrative purposes, in still other instances they become the major concern of the writer. Another feature is mentioned by MacAulay (1976: 58), who observes, in the context of Scottish Gaelic poetry, that naming brings things and people close to home. The above insights are confirmed by Evans (1973: 66), who talking about Irish habitat, heritage and history, mentions the existence of a pagan sense of communion with all nature running through the ancient tales and inspiring outstanding lyrical poetry. Yet, as observed by Mac Cana (1988: 320), the name:

[I]s not always a mere index of the place; it can produce its own resonance which may in turn colour and enhance the reality, transforming it into something which is not quite of this prosaic world.

Names give places a sense of permanence, however, the ties linking the two may, with time, become loose. Ian MacDonald's Scottish Gaelic poem Ainmeannan ('Names') touches upon this issue: ${ }^{25}$

Aonranach ainmeannan àiteachan aig an stad sinn an dràsta 's a-rithist, air an astar fhada eadar dà fhàrdaich no eadar dà shaogal: iadsan gun chaochladh ge b'e cò 'n taobh a thèid sinne suas no sìos, samhradh no sian, falbh no tighinn.

[ Lonely the names of places at which we stop now and then, on the long trail between two dwellings or between two worlds:

they unchanging

whichever way we go -

up or down, summer or storm, coming or going. ]

The complex relation between places and their names (mediated by language) is one of the major topics of Translations.

\section{Brian Friel's Translations}

Translations, one of Brian Friel's most successful and famous plays ${ }^{26}$ is set in a hedge-school in Ballybeg (or rather Baile Beag 'Small Town'), a fictional Irish-speaking community in Donegal, at the time of the British Army 1833 Ordnance Survey, on the eve of the potato famine and the subsequent introduction of English as the dominant language. The play investigates the age-old problem of defining culture, it highlights and questions the

25 In Black, ed. (1999: 620-621); the poem was first published in the Gaelic literary journal Gairm in 1980.

26 The play was first staged in Derry, on 23 September 1980, as the first production of Field Day Theatre Company, and published by Faber in 1981. 
relationship between language, culture, history and identity. The act of mapping and renaming an entire country, the attempt to standardize and impose new patterns and names gives the play its title, Translations. Ulf Dantanus (1988: 187) sees in the making of the first Ordnance Survey map of Ireland and the resultant translations and anglicizations of Irish place-names a perfect metaphor for the historical relationship between England and Ireland, even "the beginning of the rape of a country's linguistic and cultural heritage". And according to William Pratt (1999: 446) it is a figurative journey into the past. The play, however, opens itself also to other readings at different levels of interpretation. As Manus, one of the characters in The Gentle Island (1993), Friel's yet another parable of Ireland, remarks: "There's ways and ways of telling every story. Every story has seven faces" (Friel 1993: 57). Consequently, there are ways and ways of reading or re-reading every story. The present reading of Translations focuses on the sense of place and the ontological importance of names. The issue of the status of a name is first introduced in the closing lines of act one, in the exchange between, Manus and Owen, the teacher's sons (Friel 1984: 408):

Manus: (...) What's 'incorrect' about the place-names we have here?

Owen: Nothing at all. They are just going to be standardized.

Manus: You mean changed into English?

Owen: Where there's ambiguity, they'll be Anglicized.

A moment later Owen, the younger son and 'a city man', in words that involuntarily echo Shakespeare's Juliet, dismissively claims that "It's only a name". It might therefore seem that names bear an entirely arbitrary relation to their actual referent and that they are accidental. However, to use Lionel Pilkington's (1990: 288) terms, they also have an ontological importance and a private significance. The work carried out by the sappers and his own involvement in the process of collecting names and translating them, make Owen realize that the private significance cannot be dismissed and the ontological importance cannot be replaced. Therefore by the end of the play Owen changes his attitude and believes that the Irish place-names represent a cultural permanence, a heritage which must not be changed. Now he dismisses the Name-Book: "It's only a catalogue of names" (Friel 1984: 444). The magical potency of names once more becomes all-embracing.

This feature of names is universal, very characteristically, however, it becomes prominent especially in situations of uneven language contact. Witi Ihimaera (b. 1944), a contemporary Maori writer, has made a similar remark in the context of Maori-English contacts: "Reclaiming the name means reclaiming identity and confirming resilience of culture, resilience against all those kinds of things that have happened to us (...)" (in Douthwaite 2000: 30).

\section{Conclusion}

Several writers and critics have commented on the intricate relation between place-names and language (and literature). For example, Christian Fudge (1982: 9) observes in the context of Cornish that:

Place-names are useful indicators of the health of a language (...) as soon as the language around them is replaced by a foreign one, they are cut off from the living, developing language which formed them, and become fossilized names without a meaning.

And Catherine Nash (1994: 245) in an essay on the 'cartography of identity' in Irish poetry claims that:

Much contemporary Irish poetry employs ideas of landscape. Places are named. This naming is linked to ideas of language loss. The decline of language is linked, in turn, to the idea of loss of a 
distinctive life-style and of a relationship to place considered to be more intimate and authentic than that of the present. For the writer, the evocative power of the place-name provides a key to the shared social memory of a landscape whose collective meanings were part of a unifying repository of community knowledge, but for that writer loss of the language denies access to these meanings.

It follows from the above discussion, that the use of topographical names in Irish literature fulfils not only an aesthetic function, but it is also deeply rooted in the tradition, expresses the writer's local loyalty, and performs an invocative function. I wish to conclude this study by paraphrasing Brian Friel, and claim that it is not the actual landscape that rules us: ${ }^{27}$ it is images of the landscape embodied in the names and language.

University of Łódź

\section{BIBLIOGRAPHY}

Bergin, O., 1970, Irish Bardic Poetry, Dublin: Dublin Institute for Advanced Studies.

Black, R., (ed.), 1999, An Tuil: An Anthology of Twentieth Century Scottish Gaelic Poetry, Edinburgh: Polygon.

Blunt, A. \& G. Rose, (eds), 1994, Writing Women and Space: Colonial and Postcolonial Geographies, New York: Guilford Press.

Bramsbäck, B. \& M. Croghan, (eds), 1988, Anglo-Irish Literature. Aspects of Language and Culture, Volumes $1 \&$ 2, Uppsala: Almqvist and Wiksell International.

Breatnach, C., 1996, Patronage, Politics and Prose (Maynooth Monographs 5), Maynooth: An Sagart.

Burzyńska, J. \& D. Stanulewicz, (eds), 2001, From the Peripheries to the Centre. Essays in (Anglo-)Irish Literature (PASE Studies and Monographs 8), Lublin: UMCS.

Carney, J., 1967, Medieval Irish Lyrics, Dublin: The Dolmen Press.

Carney, J., (ed.), 1965, Early Irish Poetry, Cork: The Mercier Press.

Chadwick, N. K., 1927, An Early Irish Reader, Cambirdge: University Press.

Cisło, A., 2003, Tożsamość Irlandczyków w prozie odrodzenia literackiego z przełomu XIX $i$ $X X$ wieku [The Irish Identity in the Prose of the Literary Revival of the Late Nineteenth and Early Twentieth Centuries], Wrocław: Wydawnictwo Uniwersytetu Wrocławskiego.

Dantanus, U., 1988, Brian Friel. A Study, London: Faber and Faber.

Dillon, M., 1965, 'Early lyric poetry', in: J. Carney (ed.), 9-27.

Douthwaite, J., 2000, Towards a Linguistic Theory of Foregrounding, Alessandria: Edizioni dell'Orso.

Evans, E. E., 1973, The Personality of Ireland, Cambridge: Cambridge University Press.

Flower, R., 1947, The Irish Tradition, Oxford: Clarendon Press.

Friel, B., 1979, The Enemy Within, Loughcrew: The Galery Press.

Friel, B., 1984, Selected Plays, London: Faber and Faber.

Friel, B., 1993, The Gentle Island, Loughcrew: The Galery Press.

Fudge, C., 1982, The Life of Cornish, Redruth: Dyllansow Truran.

27 Cf. one of the more often quoted lines from Translations: "It is not the literal past, the 'facts' of history, that shape us, but images of the past embodied in language" (Friel 1984: 445). Friel himself develops and paraphrases George Steiner's thought, from In Bluebeard's Castle: "It is not the literal past that rules us (...). It is images of the past" (Steiner 1971: 13). 
Greene, D. \& F. O'Connor, (eds), 1967 [1990], A Golden Treasury of Irish Poetry, AD 600 - 1200, London: Macmillan [reprinted Dingle: Brandon].

Grigson, G., 1980, 'Introduction: On poems and places', in: G. Grigson (ed.), 31-34.

Grigson, G., (ed.), 1980, The Faber Book of Poems and Places, London \& Boston: Faber \& Faber.

Gwynn, E., (ed.), 1913 [1991], The Metrical Dindshenchas. Part III. Dublin: Hodges, Figgis, and Co. [reprinted Dublin: Dublin Institute for Advanced Studies].

Hannan, R., 1991, 'An Ball Uaigneach Seo: Attachment to place in Gaelic literature', in: Éire-Ireland 36 (2), 19-31.

Heaney, S., 1989, The Place of Writing, Atlanta, Georgia: Scholars Press.

Hirst, D. K. E., 1988, 'The Southern Irish poets of the late $20^{\text {th }}$ c.', in: B. Bramsbäck \& M. Croghan (eds), Volume 2, 201-210.

Hoskins, W. G., 1985, The Making of the English Landscape, Harmondsworth: Penguin Books [first published 1955].

Jarniewicz, J., 2002, The Bottomless Centre. The Uses of History in the Poetry of Seamus Heaney, Łódź: Wydawnictwo Uniwersytetu Łódzkiego.

Kearns, R. A. \& L. D. Berg, 2002, 'Proclaiming place: Towards a geography of place name pronunciation', in: Social and Cultural Geography 3 (3), 283-302.

Kiely, B., 1982, 'A sense of place’, in: Seán Mac Réamoinn (ed.), 93-109.

Kinsella, T., 1970, 'Introduction', in: The Tain, IX-XVI.

Lee, J., (ed.), 1985, Ireland. Towards a Sense of Place, Cork: Cork University Press.

MacAulay, D., 1976, 'Introduction', in: D. MacAulay (ed.), 46-68.

MacAulay, D., (ed.), 1976 [1987], Nua-Bhardachd Ghaidhlig / Modern Scottish Gaelic Poems, Edinburgh: Southside Publishers [reprinted Edinburgh: Canongate].

Mac Cana, P., 1988, 'Placenames and mythology in Irish tradition: Places, pilgrimages and things', in: G. W. MacLennan (ed.), 319-341.

McGarry, J. P., 1976, Place Names in the Writings of William Butler Yeats, Gerrards Cross: Colin Smythe.

MacLennan, G. W., (ed.), 1988, Proceedings of the First North American Congress of Celtic Studies, Ottawa 1986, Ottawa: Chair of Celtic Studies, University of Ottawa.

Mac Mathúna, L., 1989-1990, 'The topographical vocabulary of Irish: Patterns and implications', in: AINM Bulletin of the Ulster Place-Name Society, volume IV: 144-164.

Mac Mathúna, L., 2000, 'Toponyms across languages: The role of toponymy in Ireland's language shifts', in: H. Tristram (ed.), 280-302.

Mac Mathúna, L., 2006, 'What's in an Irish name? A study of the personal naming systems of Irish and Irish English', in: H. Tristram (ed.), 64-87.

Mac Mathúna, S. \& F. Maxim, (eds.), 2006, Parallels between Celtic and Slavic: Proceedings of the First International Colloquium of Societas Celto-Slavica held at the University of Ulster, Coleraine, 19-21 June 2005. Studia Celto-Slavica 1, Coleraine: TSO Publishers.

Mac Réamoinn, S., (ed.), 1982, The Pleasures of Gaelic Poetry. London: Allen Lane.

Mikhailóva, T., 2006, 'On the function of name in Irish and Slavonic incantation tradition', in: S. Mac Mathúna \& M. Fomin, (eds.), 163-173.

Minihane, J., 1993, The Christian Druids, Dublin: Sanas Press.

Murphy, G., 1956 [1998], Early Irish Lyrics, Oxford: Oxford University Press [reprinted Dublin: Four Courts Press].

Nash, C., 1994, 'Remapping the body/land: New cartographies of identity, gender and landscape in Ireland', in: A. Blunt \& G. Rose (eds), 227-250.

Neeson, E., 1985, Poems from the Irish, Dublin: Ward River Press.

Nolan, W., (ed.), 1986, The Shaping of Ireland. The Geographical Perspective, Cork and Dublin: The Mercier Press. 
Ó Cuív, B., 1986, ‘Aspects of Irish personal names', Celtica 18, 151-184.

Ó Cuív, B., 1989-1991. 'Dinnshenchas. The literary exploitation of Irish place-names', in: AINM Bulletin of the Ulster Place-Name Society, volume IV, 90-106.

O Daly, M., 1965, 'The Metrical Dindshenchas', in: J. Carney (ed.), 59-72.

O'Flanagan, P., 1986, 'Placenames and change in the Irish landscape', in: W. Nolan, (ed.), 111-122.

O’Rahilly, C., (ed.), 1976, Táin Bó Cúailnge. Recension I, Dublin: Dublin Institute for Advanced Studies.

Ó Tuama, S., 1985, 'Stability and ambivalence: Aspects of the sense of place and religion in Irish literature', in: J. Lee (ed.), 21-33.

Ó Tuama S. \& T. Kinsella, 1990, An Duanaire 1600-1900. Poems of the Dispossessed, Mountrath: The Dolmen Press.

Pilkington, L., 1990, 'Language and politics in Brian Friel's Translations', in: Irish University Review 20 (2), 282-298.

Pratt, W., 1999, 'Brian Friel's imaginary journeys to nowhere', in: World Literature Today 73 (3), 445-450.

Raine, K., 1976, 'Preface', in: J. P. McGarry, 5-7.

Schuchard, R., 1989, 'Introduction', in: S. Heaney, 2-16.

Sheeran, P., 1988, 'Genius Fabulae: The Irish sense of place', in: Irish University Review 18 (2): 191-206.

Stalmaszczyk, P., 1991-1993, 'Geographical names in Gaelic poetry: Function and problems with translation', in: AINM Bulletin of the Ulster Place-Name Society, vol V, Belfast, 71-81.

Stalmaszczyk, P., 2005, Celtic Presence. Studies in Celtic Languages and Literatures: Irish, Scottish Gaelic and Cornish, Łódź: Łódź University Press.

Stalmaszczyk, P. \& G. Elmore, 2001, 'Landscapes, places, and names in Irish literature', in: J. Burzyńska \& D. Stanulewicz (eds), 9-24.

Steiner, G., 1971, In Bluebeard's Castle. Some Notes towards the Redefinition of Culture, London: Faber and Faber.

The Tain, 1970, Translated by Thomas Kinsella from the Irish epic Táin Bó Cuailnge, Oxford: Oxford University Press.

Tristram, H., (ed.), 2000, The Celtic Englishes II, Heidelberg: Carl Winter Universitätsverlag.

Tristram, H., (ed.), 2006, The Celtic Englishes IV. The Interface between English and the Celtic Languages, Potsdam: Potsdam University Press. 